\title{
Representing school discourse stimuli
}

\author{
Elena G. Ozerova ${ }^{1 *}$, Natalia M. Goleva ${ }^{1}$, Irina S. Golubeva ${ }^{1}$, Irina M. Chebotareva ${ }^{1}$, and \\ Tatyana $V$. Yakovleva ${ }^{2}$ \\ ${ }^{1}$ Belgorod State National Research University, Department of Russian Language and Russian \\ Literature, Belgorod, Russia \\ ${ }^{2}$ Belgorod State National Research University, Department of Theory, Pedagogy and Methodology of \\ Primary Education and Fine Arts, Belgorod, Russia
}

\begin{abstract}
Discourse study in contemporary science is characterized by various approaches, whose integrative feature is the fact that this theoretical phenomenon is considered as a communicative activity and is caused by anthropocentric factors of speech generation. The representation of school discourse stimuli allows simulating the speech portrait of participants in educational activities. School discourse is a complex communicative phenomenon created by the subjects of the school educational process. It reflects the totality of accepted values and behavioral stereotypes in a particular socio-cultural space. The work aims to investigate the stimuli of school discourse. This work was conducted employing methods, such as 1) the free associative experiment; 2) quantitative analysis, which allowed identifying the actualization of the incentive perception based on quantitative data; and 3) discursive and conceptual analysis, which involved the identification of concepts, simulating them based on the conceptual totality of the means of their lexical representation in the usage. In the course of conducted study, about 600 native speakers of the Russian language were interviewed, and 9,440 associations were obtained for the school discourse stimuli. In the language consciousness of schoolchildren and teachers, associations for the "Family" stimulus were dominant, and the associative field of this stimulus was represented most broadly. The smallest number of associations was noted with regard to the "Evil" stimulus. The frequency of associations in the stimuli "Good", "Happiness", "Love", "Friendship", "Joy", and "Labor" was approximately the same. The representation of school discourse stimuli reflects the value system, worldviews, moods, and assessments of recipients. Such a study was conducted for the first time.

Keywords: school discourse, association, stimulus.
\end{abstract}

\section{Introduction}

Discourse study in contemporary science is concentrated in several areas and characterized by a multivector interpretation; however, the unifying fact is that this theoretical phenomenon is considered as a communicative activity, which is caused by anthropocentric factors of speech generation.

\footnotetext{
${ }^{*}$ Corresponding author: ozerova@bsu.edu.ru
} 
These theoretical postulates have served as motivation for the creation of nominative definitions, defined in contemporary research:

- pedagogical discourse [1-8];

- educational discourse $[9,10]$;

- educational and pedagogical discourse [11];

- school educational discourse [12];

- upbringing discourse [13];

- teaching discourse [14];

- educational and pedagogical discourse $[15,16]$.

The scientific novelty of the research consists in the associative-semantic consideration of the school discourse, which allows representing the stimuli of the educational process. The scientific novelty of the conducted research is also provided by the coined term "school discourse", as well as the results of a conducted associative experiment that allows modeling the speech portrait of the recipients.

The research hypothesis is that the school discourse is a complex communicative phenomenon created by the subjects of the school educational process, which reflects the social and cultural representations of a person, his linguistic consciousness, and is part of the process that represents the totality of accepted values and behavioral stereotypes in a particular socio-cultural space.

The research objective is to investigate the school discourse stimuli. Achieving this goal involves solving the following tasks:

1) to determine the cognitive and pragmatic significance of school discourse;

2) to conduct linguo-quantitative analysis of incentives, nominating the educational process: "School", "Teacher", "Student", "Vice principal", "School principal", "Lesson", "Review Work", etc.;

3 ) to identify culturally significant meanings and conduct a linguo-quantitative analysis of the school discourse stimuli, nominating spiritual values: "Labor", "Good", "Evil", "Happiness"; "Love", and "Friendship".

The school communication space is an intrinsic part of society since it not only teaches but also brings up the individual. Therefore, there is a need to study the speech functioning in the educational process participants, to identify the mutual influence of social medium, culture, and the subject. In the context of the anthropocentric approach in the study of discourse, the issues of individual author's perceptions are of paramount importance, but at the same time, the significance and relevance of extralinguistic factors remain.

Discourse acts as such a verbal and cogitative space that is focused by the "complex unity of the linguistic form" [17], correlates with real-time, and is included in the process of social interaction [18].

\section{Methods}

The following methods were used in the present research:

1. Free associative experiment, which was the main one in the study.

2. Quantitative analysis based on the identification of quantitative data. This method allowed representing the actualization of the concept perception based on quantitative analysis.

3. Discursive-conceptual analysis, which involved the identification of concepts, and simulating them based on the conceptual commonality of the means of their lexical representation in the usage. 


\section{Results}

The research results are presented graphically in the Figures 1 and 2.

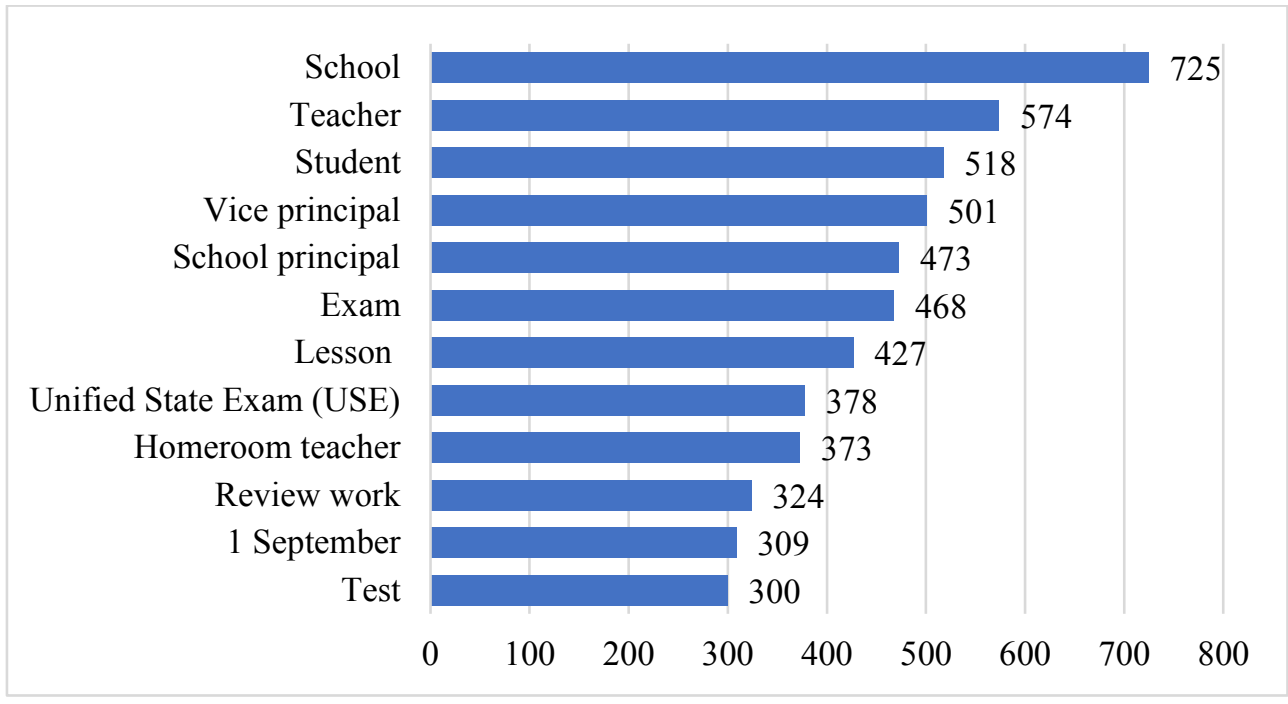

Fig. 1. School discourse stimuli representing the educational process

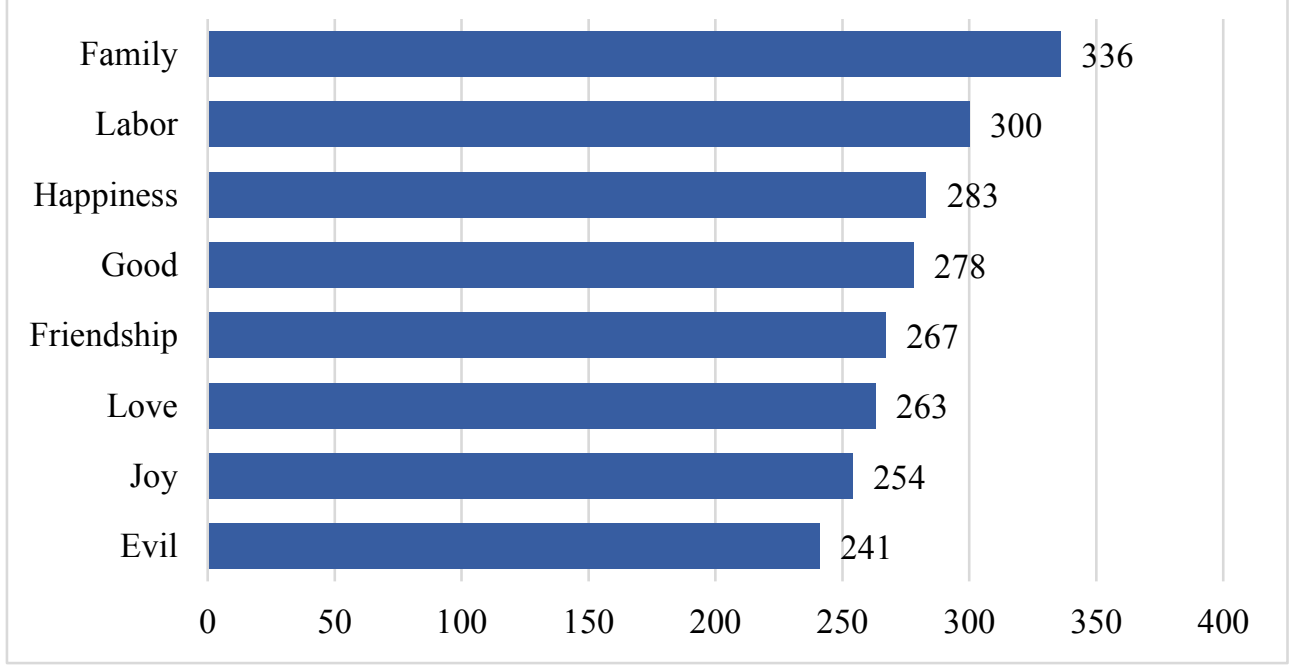

Fig. 2. School discourse stimuli representing the spiritual values

\section{Discussion}

The school discourse is represented by the intentions, goals, and conditions of the communicative interaction of the educational process, and therefore it involves the study of ways to verbalize the intellectual, spiritual, physical, and social development processes of the individual in the course of knowledge assimilation [19] and the values of the social medium, the acquisition of the necessary skills and abilities to perform various status roles, principles and norms of social behavior, and the worldview formation. 
An important issue is studying nominative factors in school communication associated with the perception of school reality, and allowing identifying the extralinguistic originality of school discourse.

School discourse is a complex communicative phenomenon created by the educational process subjects, functioning in the school space, which reflects the social and cultural representations of a person, his linguistic consciousness, and is part of the process that represents the totality of accepted values and behavioral stereotypes in a particular sociocultural space.

The problem of representing knowledge and ways of reflecting the world in the human mind, called mental representation, is currently a relevant issue for cultural linguistics. "It is the mental representations of knowledge that determine the value-cognitive space of the linguistic picture of the world, which exactly is the main subject of cultural linguistics. This is due to the nature and essence of culture, which is determined by the special relationship of thinking, consciousness, and language, generating cultural-bearing meanings" [20].

Gaining access to the consciousness of recipients is possible using a free-associative experiment to analyze the representation of school discourse stimuli that nominate the educational process. These stimuli include "School", "Teacher", "Student", "Vice principal", "School principal", "Review work", "Test", "Exam", "USE" (Unified State Exam), "Homeroom teacher", "1 September", and "Lesson".

Besides, one of the tasks of the present research was to determine the culturally significant meanings of school discourse stimuli that nominated spiritual values: "Good", "Evil", "Labor", "Love", "Friendship", "Happiness", "Joy", and "Family". These concepts occupy an important place in the daily life of the educational process participants, representing the social and educational activities of the recipients, and thus act as discourse-forming factors.

The research material included experimentally obtained associative responses of native speakers of Russian. In the course of the conducted experiment, about 600 native speakers of Russian (510 schoolchildren from 3rd to 11 th grades, and 90 teachers) were interviewed, and 9,440 associations were obtained.

In the language consciousness of schoolchildren and teachers, the dominant associations were "School" (725 associations), "Teacher" (574 associations), "Student" (518 associations), "Vice principal" (501 associations), "School principal" (473 associations), "Lesson" (427 associations), "Exam" (468 associations), "USE" (378), "Homeroom teacher" (373), "Review work" (324), "1 September" (309), and "Test" (300). The associative field of these stimuli was the most extensive.

The smallest number of associations was noted for the following stimuli: "Farewell Bell" (281), “Textbook" (250), "Blackboard" (248), "Desk" (230), "Vacation" (249), "Homeroom period" (198), "School uniform" (197), and "Subject-based classroom" (195).

The educational process includes training and upbringing: the spiritual and valuesemantic development of schoolchildren is one of the most important tasks of the pedagogical system. Value-semantic orientations have both socializing and person-centered developing significance. The authors believe that the analysis of value preferences is extremely important because it allows exploring the national language consciousness and building a model of the linguistic identity of school discourse participants. The language captures and reflects the system of values, worldviews, moods, and assessments of recipients.

In the language consciousness of schoolchildren and teachers [21], associations caused by "Family" stimulus were dominant (336 associations), and the associative field of this stimulus was represented most broadly.

The smallest number of associations was noted for the stimulus: "Evil" (241). The frequency of associations in the other stimuli was approximately the same: "Good" (278), "Happiness" (283), "Love" (263), "Friendship" (267), "Joy" (254), "Labor" (300). It is worth noting that the number of associations received for the stimuli of school discourse, 
nominating the educational process, was greater than that for the stimuli of value-semantic potential.

The associative field of the concepts "School", "Vice principal", "School principal", and "Labor" included lexemes with both a negative ("one can hang due to school", "hell", "fear", "chagrin" were verbal responses to the stimulus "School"; and "fatigue", "boredom", and "laziness" were responses to the stimulus "Labor"), and a positive connotation ("good", "favorite", "joy"). The ratio of negatively and positively accented responses was approximately the same.

It was revealed that the associative field of the concepts "Lesson", "Review work", "Test", "1 September", "Exam", and "USE" also included negative and positive connotations, but pejorative vocabulary prevailed significantly.

The associative field of the concepts "Love", "Friendship", "Family", "Homeroom teacher" also included both ameliotory and pejorative vocabulary, but positive responses dominated ("second mother", "care", "support", "savior angel"), although negative responses, such as "shout", "anger", and "tyrant" were also noted in the course of the experiment).

The associative field of the concept "Teacher" also included both ameliotory ("wise", "mentor", "sun"), and pejorative responses ("slave", "tortured", "tyrant"). A tendency to increase negatively accented responses was revealed in older schoolchildren. Primary schoolchildren manifested predominance of positively accented associations, such as "good", "best" (52\%), schoolchildren in grades 5-8 also revealed a large number of positively accented verbal responses $(42 \%)$, while in schoolchildren of grades $9-11$, neutral-accented associations dominated (72\%).

The associative field of the concept "Student" included verbal responses with ameliotory connotation ("angel", "honor student", "diligent") and with pejorative accent ("loutish behavior", "insolent", "stupid"). Negatively accented vocabulary increased with the increase in schoolchildren's age. Thus, primary school children did not reveal negatively accented responses, while in senior schoolchildren, the number of negatively accented lexemes dominated, pejorative responses were not revealed only with respect to the "Happiness" and "Joy" stimuli.

\section{Conclusion}

The conducted study has shown that the respondents used several forms of verbalization of the studied concepts of school discourse, nominating the educational process:

1) word-form responses (individual lexical units): "friend", "ratings", "fair-minded";

2) word-combination responses: "parent-teacher interview", "calling parents", "best person", "educator of children";

3) sentences-based responses: "don't make any noise", "the person I see every day".

Such many response types indicate a variety of verbalization forms of the concept under study.

The resulting responses often reflect extralinguistic factors.

Verbal responses to the stimulus "Exam", namely, "form", "black ink pen", "points", "option number", "video cameras", "someone else's school" reflect the procedure for conducting the Basic State Examination and Unified State Exam. Schoolchildren take these exams at a school other than their own, tasks are performed with black gel pens filling in standard forms, and for each completed task the student receives points. The entire exam procedure is recorded on CCTV cameras.

Thus, one can note that the influence of extralinguistic factors increases. The school discourse represents the peculiarity of communicative interaction, which actualizes the phenomenon of linguistic personality in society. 
It should be noted that anthropocentric resources represent a dynamic system of associative links since they are directly dependent on the person - the subject of language and culture, that is, due to the associative experiment, one can draw conclusions concerning the values and worldview of contemporary schoolchildren.

The results obtained allow drawing conclusions concerning the socio-cultural status of recipients, making a verbal and cogitative portrait of contemporary schoolchildren and teachers. The research outcomes make it possible to represent the functioning features of the recipients' language consciousness, as well as the ways of constructing speech utterance.

\section{References}

1. V.I. Karasik, Yazykovoy krug: lichnost', kontsepty, diskurs [Language circle: personality, concepts, discourse] (Gnozis, Moscow, 2004)

2. V.I. Karasik, Russian Language Abroad, 5(264), 4-8 (2017)

3. A.M. Nikitina, Evfemizmy v rechi uchitelya kak sredstvo garmonizatsii pedagogicheskogo diskursa [Euphemisms in the teacher's speech as a means of harmonizing pedagogical discourse]. Thesis of the candidate of pedagogical sciences (Moscow State Pedagogical University, Moscow, 2015)

4. L. B. Nikitina, Gumanitarnyie Issledovaniya, 2(27), 93-97 (2020) http://dx.doi.org/10.36809/2309-9380-2020-27-93-97

5. Y.V. Shcherbinina, Vvedeniye v pedagogicheskiy diskurs [Introduction to pedagogical discourse] (Infra-M, Moscow, 2015)

6. V.V. Koreneva, Osobennosti pedagogicheskogo diskursa uchitelya nachal'nykh klassov [Features of the pedagogical discourse of the primary school teacher], in Aktual'nyye psikhologo-pedagogicheskiye, filosofskiye, ekonomicheskiye i yuridicheskiye problemy sovremennogo rossiyskogo obshchestva [Actual psychological, pedagogical, philosophical, economic and legal problems of modern Russian society], 93-114 (Zebra, Ulianovsk, 2017)

7. N.N. Shpilnaia, Comunication Studies, 4(18), 45-58 (2018). http://dx.doi.org/10.25513/2413-6182.2018.4.45-58

8. E.Y. Grigorieva, Pedagogicheskiy diskurs v lingvokul'turologicheskom rassmotrenii [Pedagogical discourse in linguistic and cultural consideration], in Z. Sładkiewicz, A. Klimkiewicz (Eds.), Perswazja językowa w różnych dyskursach, 219-227 (Wydawnictwo Uniwersytetu Gdańskiego, Gdańsk, 2019)

9. O. Santa Ana, Political Linguistics, 1(21), 97-114 (2007)

10. B.V. Penkov, Theoretical and Applied Linguistics, 3, 111-116 (2015). http://dx.doi.org/10.18413 / 2313-8912-2015-1-3-110-116

11. E.A. Kozhemiakin, Nauchnyye Vedomosti Belgorodskogo Gosudarstvennogo Universiteta. Seriya: Filosofiya. Sotsiologiya. Pravo, 14(85)(12), 25-35 (2010)

12. I.N. Bogutskaya, Shkol'nyy obrazovatel'nyy diskurs: lingvokul'turologicheskiye osnovy yego formirovaniya [School educational discourse: linguocultural foundations of its formation] Thesis of Candidat of philological sciences (Tyumen State University, Tyumen, 2010)

13. Tsinkerman T.N. Science Journal of Volgograd State University. Linguistics, 5(29), 101-108 (2015). http://dx.doi.org/10.15688/jvolsu2.2015.5.11

14. T.A. Milyohina, Prichiny vozniknoveniya i sposoby preodoleniya kommunikativnykh riskov $v$ prepodavatel'skom diskurse [Causes of occurrence and ways of overcoming 
communication risks in teaching discourse], in Proceedings of the 1st Scientific and Practical Conference with International Participation Pedagogicheskoye Vzaimodeystviye: Vozmozhnosti i Perspektivy [Pedagogical Interaction: Opportunities and Prospects], 14 May 2019, Saratov, Russia, 260-268 (2019)

15. S.V. Pervukhina, Uchebno-pedagogicheskiy diskurs: adaptatsiya teksta [Educational and pedagogical discourse: adaptation of the text], in Proceedings of the 5th International Scientific-Practical Conference Kommunikativnyye Tekhnologii v Obrazovanii, Biznese, Politike i Prave: Problemy i Perspektivy Realizatsii v Sovremennoy Tsifrovoy Srede [Communication Technologies in Education, Business, Politics and Law: Problems and Prospects for Implementation in the Modern Digital Environment], 06-08 December 2018, Volgograd, Russia, 237-238 (2019)

16. I.P. Cherkasova, E.A. Alymova, Vestnik Permskogo Nacional'nogo Issledovatel'skogo Politehničeskogo Universiteta. Problemy Âzykoznaniâ i Pedagogiki, 1, 35-42 (2020)

17. T.A. van Dijk, Yazyk. Poznaniye. Kommunikatsiya [Language. Cognition. Communication] (Progress, Moscow, 1989)

18. M. Khutoranskiy, Vysshee Obrazovanie v Rossii, 27(10), 146-160 (2018). https://doi.org/10.31992/0869-3617-2018-27-10-146-160

19. J. Loughran, Teachers and Teaching, 25(5), 523-535 (2019)

20. N.F. Alefirenko, Lingvokul'turologiya: Tsennostno-smyslovoye prostranstvo yazyka [Cultural linguistics: Value-semantic space of language] (Flinta, Nauka, Moscow, 2010)

21. I. Männikkö, J. Husu, Teaching and Teacher Education, 77, 126-137 (2019). http://dx.doi.org/10.1016/j.tate.2018.09.016 